\title{
The Correlation of Coping Stress and Social Support with Academic Stress on Distance Learning
}

\author{
Diana Lilik Kusumawati Dewi ${ }^{\left.1^{*}\right)}$, Muslikah ${ }^{2}$ \\ ${ }^{1,2}$ Universitas Negeri Semarang \\ *Corresponding author, e-mail: diana.lilik099@gmail.com
}

Received August 02, 2021; Revised August 31, 2021;

Accepted Sept. 20, 2021; Published Online 2021-10-01

\section{Conflict of Interest} Disclosures:

The authors declare that they have no significant competing financial, professional or personal interests that might have influenced the performance or presentation of the work described in this manuscript.

\begin{abstract}
This study discusses the correlation between coping stress and social support with academic stress in distance learning for 10th grade students of SMA Negeri in the District of Ngaliyan Semarang. The purpose of this study is to determine the relationship between variables and obtain information on the level of each variable with a sample of 255 students. The method in this research is ex-post facto quantitative. The results of the descriptive analysis showed that the level of stress coping of the tenth graders of SMA Negeri in Ngaliyan Semarang District was in the low category $(M=2.56)$, the level of social support was high $(\mathrm{M}=3.04)$, and the level of academic stress in distance learning was high $(M=2,67)$. The results of multiple regression analysis show that there is a negative and significant relationship between coping stress and academic stress in distance learning students $(\mathrm{t}=-10,854,=-0.646, \mathrm{p}=<0.05)$, social support has no significant correlation. significant with academic stress on distance learning students $(\mathrm{t}=-0.908,=-0.054, \mathrm{p}=>0.05)$, and there is a positive and significant correlation between stress coping and social support simultaneously on academic stress in distance learning students $\left(\mathrm{R}=0.681 ; \mathrm{R}^{2}=0.464 ; \mathrm{F}=109.083\right.$, $\mathrm{p}=<0.05$ ). Based on the results of the research, , it is hoped that the guidance and counseling teachers can provide guidance and counseling services to be able to reduce students' academic stress levels both individually and in groups, increase students' stress coping levels and services to maintain students' social support levels.
\end{abstract}

Keywords: Coping Stress, Social Support, Academic Stress.

\section{Introduction}

Academic stress is a condition of incompatibility that occurs, namely demands from the environment with actual resources by students so that students become burdened by various pressures and demands (Rahmawati, 2012). Individuals who are experiencing stress will show physical symptoms, emotional symptoms, and behavioral symptoms (Inayatillah, V. 2015). Desmita (2010) said that academic stress is pressure and thoughts caused by academic stressors. Academic stressor is stress that comes from the learning process such as: pressure to go to class, length of study, cheating, many assignments, low achievement, decisions in determining majors and careers, and anxiety when facing exams (Rahmawati, W. K. 2017). 
In addition, the source of academic stress experienced by students is distance learning during the Covid19 pandemic. Covid-19 is an infectious disease caused by a newly discovered type of coronavirus. To reduce the number from the spread of Covid-19 and continue learning, the implementation of learning is carried out using an online system, namely distance learning (PJJ) which has been carried out since March 2020. Online learning is defined as learning that uses videos, images, audio, and text articles. digitally (Basilaia \& Kvavadze: 2020) and internet assistance (Zhu \& Liu: 2020). The learning system is carried out without meeting face to face, carried out through a distance learning system by learning from their respective homes. Distance learning activities during this pandemic can be done by utilizing the availability of various platforms that are able to support the implementation of online learning at home. These platforms are in the form of WhatsApp, Email, Google Classroom, Moodle, Zoom, and others (Gunawan: 2020).

However, it is not without obstacles, the distance learning style through learning from home during the Covid-19 pandemic seems to have obstacles such as the absence of an internet network at home, internet packages that run out quickly, and a lot of tasks that make students prone to stress. and tired. Even at home, students feel tired and lack rest. Many tasks given by teachers to students are considered heavy so that it makes students feel stressed.

Research conducted by Fitriani Rahayu (2014) said that the stress level in accelerated students of SMAN 2 South Tangerang City, namely students who had stress levels were in the higher category more, namely $51.4 \%$ compared to the low percentage of $48.6 \%$. The results of this study illustrate that many of the students of SMAN 2 in South Tangerang City experience academic stress. This happens because accelerated students experience a lot of solid demands on learning activities and tasks given by the teacher so that students feel tired to stressful conditions. If these things are allowed to continue, it can have an impact on the physical or psychological health of students.

Based on a preliminary data study conducted by researchers at SMA Negeri in the District of Ngaliyan Semarang, 53\% of students experienced academic stress in the high category, while only a few experienced academic stress in the low category. To be able to overcome this, of course, students are expected to have the right coping strategies (Naviska, 2012).

Yudiati \& Rahayu (2017) say that coping is a reaction to mental stress, about what is experienced, thought and reduces the negative impact of situations that individuals experience. Factors that influence individuals in using coping stress are internal factors, namely factors that come from the individual, such as self-efficacy (Rizky, Zulharman, and Risma, 2012), optimism (Ningrum, 2011), emotional intelligence (Saptoto, 2010) and external factors namely factors that come from the environment such as attachment (Bayani and Sarwasih, 2013), as well as social support (Hasan and Rufaidah, 2013). Such as concrete support given by friends, namely lending something, helping with assignments, providing information and also support is given through awards and positive assessments of individuals (As Sururi and Muslikah, 2020). Hasan and Rufaidah (2013) say that the existence of social support from the environment will make individuals more confident, accept reality and think positively. Social support can improve the way a person faces or solve problems and reduce stress responses through coping with stress (Johnson in Prayascitta, 2010).

The research that will be carried out is important to see that high student academic stress can hinder the learning process, thus making teaching and learning activities ineffective. Thus, researchers are interested in researching the relationship between coping stress and social support with academic stress on distance learning students, with the hope that the results of research conducted by researchers can be the basis for counseling guidance teachers to make a service both individually and in groups at the same time. distance learning during a pandemic.

\section{Method}

\section{Research Design}

The population of this research is the students of class X SMA Negeri in the District of Ngaliyan Semarang, which consists of SMA N 07 Semarang and SMA N 08 Semarang. The research sample was 255 students who had been calculated using the Isaac \& Michael table with an error rate of $5 \%$. The sampling technique used is Simple Random Sampling, which is a sampling method that is carried out randomly without regard to the strata contained in the population (Sugiyono, 2017). The analysis used is descriptive quantitative analysis and multiple regression. 
The method used in this research is to use quantitative expost facto correlational design. This study uses a psychological scale for data collection in the study which includes the coping stress scale, social support scale and distance learning academic stress scale made by researchers using the Likert model. The validity of the instrument uses construct validity as a form of testing, after compiling the instrument, it is then consulted with an expert, namely the lecturer, then tested and then seen the validity of the instrument, which is measured using the product moment correlation formula. The reliability of the academic stress scale instrument shows Cronbach's alpha value of 0.872 (>0.312 $\mathrm{r}$ table); coping stress 0.861 (> $0.312 \mathrm{r}$ table); social support 0,921( $>0,312 \mathrm{r}$ table), so it is declared reliable.

Student academic stress was measured using an academic stress scale consisting of 27 items. The scale is based on aspects of academic stress by Sarafino \& Smith, namely physiological, emotional, cognitive and behavioral. Furthermore, students' coping stress was measured using a stress coping scale consisting of 28 items, the scale was arranged based on the types of stress coping according to Lazarus and Folkman, namely coping that focuses on emotions (Emotion focused coping) and coping that focuses on problems (problem focused coping). Then students' social support was measured using a social support scale consisting of 26 items, the scale was arranged based on the aspects of social support according to House, namely emotional support, reward support, instrumental support, and informative support.

\section{Results and Discussion}

\section{Results of Descriptive Quantitative Analysis.}

This section contains the results of a descriptive analysis that shows the level of stress coping, social support and academic stress in distance learning for X grade students of SMA Negeri in the District of Ngaliyan Semarang. The results of the data can be seen in the table below:

Tabel 1. Inter-Variable Level

\begin{tabular}{lllll}
\hline No & Variable & Mean & SD & Category \\
\hline 1 & Coping Stress & 2,56 & 0,32 & Low \\
2 & Social Support & 3,04 & 0,49 & High \\
3 & Academic Stress & 2,67 & 0,4 & High \\
\hline
\end{tabular}

Based on table 1, it shows that the level of stress coping of state high school students in Ngaliyan Semarang district is in the low category, the level of social support of public high school students in Ngaliyan Semarang district is in the high category, then the academic stress level of public high school students in Ngaliyan Semarang district is in the category tall. Then the level per indicator is seen in table 2 as follows:

Tabel 2. Rate per Indicator

\begin{tabular}{ccccc}
\hline Variable & Indicator & Mean & SD & Category \\
\hline Coping Stress & Emotion Focused Coping & 2,52 & 0,32 & Low \\
& Problem Focused Coping & 2,61 & 0,39 & High \\
Social Support & Emotional Support & 2,97 & 0,64 & High \\
& Award Support & 2,85 & 0,65 & High \\
& Instrumental Support & 3,32 & 0,54 & Very High \\
& Informative Support & 3,09 & 0,5 & High \\
Academic Stress & Physiological & 2,72 & 0,58 & High \\
& Emotion & 2,98 & 0,37 & High \\
& Cognitive & 2,57 & 0,55 & Low \\
& Behavior & 2,31 & 0,61 & Low \\
\hline
\end{tabular}


Based on table 2 shows that the emotion focused coping indicator in the low category has a mean of 2.52; $\mathrm{SD}$ is 0.32 . While the problem focused coping indicator has a mean of $2.61 ; \mathrm{SD}$ is 0.39 . Based on these data, it can be seen that problem focused coping is in a higher category than emotion focused coping indicators.

Furthermore, emotional support in the high category has a mean of 2.97; SD of 0.64 ; award support in the high category has a mean of 2.85; SD of 0.65 ; informative support in the high category has a mean of 3.09; SD is 0.5. While informative support has a mean of 3.32; SD is 0.54. Based on these data, it can be seen that instrumental support is in a higher category than other indicators.

Then the academic stress variable on physiological indicators is categorized as high, which has a mean of 2.72; SD of 0.58; the emotion indicator in the high category has a mean of 2.98; SD of 0.37; cognitive indicators in the low category have a mean of 2.57 ; $\mathrm{SD}$ is 0.55 . While the behavioral indicators have a mean of 2.31 ; $\mathrm{SD}$ is 0.61 .

\section{Multiple Regression Test Results.}

The results of the multiple regression test will describe the relationship between variables, which include the relationship between coping stress and academic stress, the relationship between social support and academic stress, the relationship between coping stress and social support with student academic stress.

\subsection{The Relationship between Coping Stress and Academic Stress}

Regression analysis of coping stress with student academic stress is used to test the hypothesis which reads "there is a negative and significant relationship between coping stress and distance learning academic stress on students." The results of the multiple regression test are shown in the table below.

Table 3. Multiple Regression Test Results

\begin{tabular}{ccccccc}
\hline Prediktor & $\mathbf{R}$ & $\mathbf{R}^{\mathbf{2}}$ & $\mathbf{F}$ & $\mathbf{B}$ & $\mathbf{T}$ & $\mathbf{P}$ \\
\hline Coping Stress and Social Support & 0,681 & 0,464 & 109,083 & - & - & 0,000 \\
Coping Stress & - & - & - & $-0,646$ & $-10,854$ & 0,000 \\
Social Support & - & - & - & $-0,054$ & $-0,908$ & 0,365 \\
\hline
\end{tabular}

Based on the results of the analysis in table 3 , the results obtained are that there is a negative and significant relationship $(\beta=-0.646 ; t=-10,854 ; 0.000<0.05$ ). So it shows that the hypothesis which states "There is a negative and significant relationship between coping stress and distance learning academic stress in class X SMA Negeri in the District of Ngaliyan Semarang" can be accepted.

\subsection{The Relationship between Social Support and Academic Stress}

Regression analysis of social support and student academic stress was used to test the second hypothesis, namely "There is a negative and significant relationship between social support and distance learning academic stress in class X SMA Negeri in the District of Ngaliyan Semarang". Based on the results of the analysis in table 7 , it is found that there is no significant relationship ( $\beta=-0.054 ; t=-0.908 ; 0.365>0.05)$. So this shows that the hypothesis which states "There is a negative and significant relationship between social support and distance learning academic stress in class X SMA Negeri in the District of Ngaliyan Semarang" is rejected.

\subsection{The Relationship between Coping Stress and Social Support with Academic Stress}

Multiple regression analysis was used to test the third hypothesis, namely "There is a significant relationship between coping stress and social support with distance learning academic stress in class X SMA Negeri in the District of Ngaliyan Semarang". Based on the results of multiple regression analysis showed that coping stress and social support simultaneously there was a significant relationship with students' academic stress, it was known that $\mathrm{R}=0.681, \mathrm{R} 2=0.464 \mathrm{~F}=109.083, \mathrm{p}=<0.05$. So it shows that the hypothesis which states "There is a significant relationship between coping stress and social support with distance learning academic stress in class X SMA Negeri in the District of Ngaliyan Semarang" can be accepted. 
Based on the results of the research, it is known that the students of class X SMA Negeri in Ngaliyan District are in the high category of academic stress levels. The results of the per-indicator descriptive analysis show that emotional indicators have a high contribution to academic stress in distance learning that is felt by students of class X SMA Negeri in the District of Ngaliyan Semarang. Academic stress experienced by students in distance learning during the Covid-19 pandemic such as task demands that are not in accordance with the student's capacity, difficulties in understanding learning materials, boredom studying from home and so on. The demands imposed by online learning methods make them depressed and eventually cause symptoms of stress (Muslim, 2020). Livana, Mubin, \& Basthomi (2020) said that teaching and learning tasks during a pandemic had a significantly more significant effect on stress levels when compared to pre-pandemic tasks. The emotional tension felt by students in dealing with academic demands so that it has an impact on students' physical and mental health (Dixit and Singh, 2015).

In general, students of class X SMA Negeri in the District of Ngaliyan Semarang have a low level of stress coping. Coping stress is an effort made by individuals both physically and psychologically to overcome a problem or reduce demands that cause stress. The results of the descriptive analysis of the contribution of the Problem Focused Coping indicator in the high category. The use of problem-focused coping strategies is usually done when individuals believe that when dealing with stress that is being experienced practically by assuming the problem at hand can be overcome directly. Due to the implementation of distance learning, the perceived stressor is in the form of many and piling tasks given by the teacher. To overcome this problem based on problem focused coping, direct intervention is carried out on stressors by trying to complete the piled up tasks and other responsibilities given by the teacher. As in the research conducted by Nurfitriana (2014), which shows that the Problem Focused Coping strategy is more widely used by students because the stressors they experience are school assignments that are not small and difficult and there is a tendency to cheat on friends' answers.

Social support for class X State Senior High School students in Ngaliyan District is in the high category. The results of the per-indicator descriptive analysis show that the instrumental support indicator has a very high contribution to the tenth grade students of SMA Negeri in the District of Ngaliyan Semarang. Instrumental support is support that is given directly in the form of material from other people. Support provided directly by families and teachers such as the fulfillment of facilities and assistance in the implementation of distance learning. In fulfilling facilities such as the need for school supplies, comfortable study rooms, as well as a conducive situation when students conduct online learning at home during distance learning.

Based on the calculations that have been done, the researcher states that in this study there is a negative and significant relationship between coping stress and academic stress in distance learning. So that means the higher the coping stress, the lower the student's academic stress. On the other hand, if the coping stress level is low, the student's academic stress level will be higher. There are 2 types of stress coping, namely coping that focuses on emotions (emotion focused coping) and coping that focuses on problems (problem focused coping). The results of this study indicate that the use of coping strategies that focus on problems (problem focused coping) is higher than the use of coping strategies that focus on emotions (emotion focused coping). The use of problem focus coping strategies is carried out when individuals believe that when they are able to overcome the stress of the mind that is felt practically by assuming the problems they face can be overcome directly. This is because during the implementation of distance learning, stressors are experienced in the form of many and piled tasks given by the teacher, difficulties in understanding learning material so to overcome this it is necessary to intervene directly against stressors by completing tasks that accumulate and trying to meet the required facilities. Too many assignments, difficulty in understanding lessons, and busy school time are academic stressors that are often experienced by students. The tasks that are too many are caused by the lack of virtual interaction and the limited facilities in conducting distance learning. So it is necessary to have good stress coping management to be able to reduce academic stress experienced by students in implementing distance learning during a pandemic.

Furthermore, based on the analysis of the results of the study, it shows that there is no negative and significant relationship between social support and academic stress in distance learning for class X SMA Negeri Semarang sub-districts, which means that the decrease in academic stress levels is not solely related to support. student social. In line with the results of research conducted by Hasan (2012) shows that social support is not significantly correlated with academic stress. There are other things that affect academic stress more. This can lead to gaps and plurality of interaction patterns within the group choosing to rely more on 
individual abilities than the group. According to Sarafino (2012) the concept of stress including academic stress is a complex matter involving psychological, biological, and physical aspects so that many factors can influence it. So that the results of this study, namely social support, there is no significant relationship with academic stress on distance learning students because there are other things that can affect students' academic stress more.

Then the results of the study show that there is a negative and significant relationship between coping stress and social support with academic stress in distance learning for class X SMA Negeri Semarang District students together, which means the higher the level of stress coping and student social support. together, the level of academic stress will be lower. On the other hand, if the level of stress coping and social support is low, the academic stress level will be higher.

American College Health Association (dalam Kadapatti \& Vijayalaxmi, 2012) mengatakan bahwa kendala yang terbesar bagi perilaku akademik yaitu stres akademik. Stres akademik mempunyai banyak dampak negatif yakni bukan hanya dalam proses pembelajaran saja tetapi juga terhadap kesehatan fisik. Oleh karena itu untuk mengurangi tingkat stres akademik diperlukan faktor-faktor yang dapat mendukung hal tersebut yaitu faktor dari individu (internal) serta dari luar (eksternal), agar tidak mengganggu dalam proses pembelajaran maupun terhadap kesehatan fisik. Dukungan sosial bisa meningkatkan cara individu untuk menghadapi atau memecahkan permasalahan dan pengurangan respon stres melalui coping stress (Johnson dalam Prayascitta (2010). Sakti (2015) juga menambahkan sesorang yang mendapat dukungan sosial maka akan lebih mudah mengelola coping dibanding individu yang belum mendapat dukungan sosial, sehingga hal tersebut dapat mereduksi stres akademik yang dialami siswa.

\section{Conclusion}

Based on the results of the research described by the researchers regarding the relationship between coping stress and social support with academic stress on distance learning students, it was concluded that the level of coping stress was in the low category, social support was in the high category, and distance learning academic stress was in the high category. a negative and significant relationship to academic stress in distance learning for class X SMA Negeri Semarang District; Social support did not show a significant relationship to academic stress in distance learning for class X SMA Negeri Semarang District; Coping stress and social support simultaneously showed a negative and significant relationship to academic stress in distance learning for class X SMA Negeri Semarang District.

The limitation in this study is that the researcher only looks for correlations between variables, the researcher does not provide treatment/intervention to students. Further researchers can develop the results of this study by conducting intervention/counseling treatment, such as conducting experimental research to reduce the level of academic stress experienced by students.

\section{Acknowledgment}

The preparation of this research could not be separated from the help, guidance and support from various parties, especially Ms. Muslikah who always took the time, energy, and thoughts and always provided motivation in the preparation of this research from beginning to end.

\section{References}

As Sururi \& Muslikah. (2020). Hubungan Dukungan Sosial Teman Sebaya Dan Aktualisasi Diri Dengan Harga Diri Remaja Panti Asuhan Di Purbalingga. Jurnal Empati Bimbingan dan Konseling. 7 (1), 3642.

Basilaia, G., \& Kvavadze, D. (2020). Transition to Online Education in Schools during a SARS-CoV-2 Coronavirus (COVID-19) Pandemic in Georgia.

Desmita. (2010). Psikologi Perkembangan Peserta Didik. Bandung: Remaja Rosdakarya. 
Gunawan, G., Suranti, N. M. Y., \& Fathoroni, F. (2020). Variations of Models and Learning Platforms for Prospective Teachers During the COVID-19 Pandemic Period. Indonesian Journal of Teacher Education, 1(2), 61-70.

Hasan, A. B. (2012). Disiplin Beribadah: Alat Penenang Ketika Dukungan Sosial Tidak Membantu Stres Akademik. Jurnal Al-Azhar Indonesia Seri Humaniora.

Hasan, N., \& Rufaidah, E. R. (2013). Hubungan antara dukungan sosial dengan strategi coping pada penderita stroke RSUD Dr. Moewardi Surakarta. TALENTA, 2(1), 41-62.

Inayatillah, V. 2015. Hubungan antara adversity question dengan kecenderungan stres dalam menyelesaikan tugas akhir (skripsi) pada mahasiswa (Doctoral dissertation, STIKES'Aisyiyah Yogyakarta).

Kadapatti, M., \& Vijayalaxmi, A. (2012). Stressor of academic stress- a study on Pre-university students. Indian J.Sci.Res., 1(3), 171-175.

Naviska, Nadia. (2012). Gambaran Mekanisme Koping Siswa Kelas 3 SMA di SMAN 1 Purwakarta Tahun Ajaran 2011/2012 Menjelang ujian Nasional. Skripsi, Universitas Indonesia.

Ningrum, D. W. (2011). Hubungan optimisme dan coping stress pada mahasiswa UEU yang sedang menyusun skripsi. Jurnal Psikologi. 9(1), 41-47.

Nurfitriana. (2014). Strategi Coping Stress Siswa terhadap Tugas Seolah di SMK Farmasi Yamasi Makassar. Skripsi, Universitas Hasanuddin.

Prayascitta, P. (2010). Hubungan antara coping stress dan dukungan sosial dengan motivasi belajar remaja yang orangtuanya bercerai. Skripsi, Universitas Sebelas Maret Surakarta.

Rahmawati, D. D. 2012. PengaruhSel-Efficacy terhadap Stres Akademik pada Siswa Kelas 1 Rintisan Sekolah Bertaraf Internasional (RSBI) di SMP Negeri 1 Medan.

Rizky, E., Zulharman., \& Risma, D. (2014). Hubungan efikasi diri dengan coping stress pada mahasiswa angkatan 2012 Fakultas Kedokteran Universitas Riau. JOM FK. 1(2), 1-8.

Sakti, E. D. D. (2015). Hubungan antara dukungan sosial dengan coping stress pada siswa akselerasi. Naskah Publikasi. Falkutas Psikologi, Universitas Muhammadiyah Surakarta.

Sarafino, E. P., \& Smith, T. W. (2012). Health psychology: biopsychosocial interactions, 7th/ed. John Wiley $\&$ Sons, Inc.

Sugiyono. (2012). Metode Penelitian Kuantitatif, Kualitatif dan R\&G. Bandung: Alfabeta

Yudiati, E. A., \& Rahayu, E. (2017). Coping stress dan kecemasan pada orang-orang pengidap hiv/aids yang menjalani tes darah dan VCT (Voluntary Counseling Testing). Semarang: Prosiding Temu Ilmiah X Ikatan Psikologi Perkembangan Indonesia.

Zhu, X., \& Liu, J. (2020). Education in and After Covid-19: Immediate Responses and LongTerm Visions.

Article Information (Supplementary)

Conflict of Interest Disclosures:

The authors declare that they have no significant competing financial, professional or personal interests that might have influenced the performance or presentation of the work described in this manuscript.

Copyrights Holder: $<$ dewi $><2021>$

First Publication Right: BISMA The Journal of Counseling

https://doi.org/10.xxxx/xxxxx

Open Access Article | CC-BY Creative Commons Attribution 4.0 International License.

@creative

Word Count: 